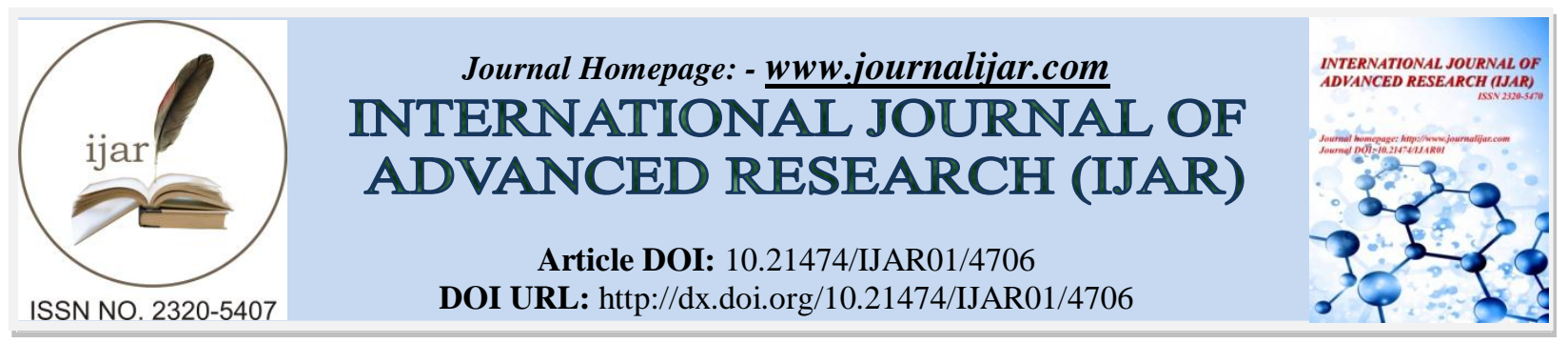

RESEARCH ARTICLE

\title{
A COMPARATIVE CLINICAL STUDY OF ARKA KSHARA SUTRA AND APAMARGA KSHARA SUTRA IN THE MANAGEMENT OF BHAGANDARA(FISTULA IN ANO).
}

\author{
Dr. narendrasinh thakor ${ }^{1}$, Dr. nilesh jethva ${ }^{2}$ and Dr. hemant Toshikhane ${ }^{3}$. \\ 1. pg scholar dept.of shalya tantra parul institute of ayurved,Vadodara. \\ 2. co-guide parul institute of ayurved,Vadodara. \\ 3. guide parul institute of ayurved,Vadodara.
}

\section{Manuscript Info}

Manuscript History

Received: 2 May 2017

Final Accepted: 4 June 2017

Published: July 2017

Key words:-

kshara, apamarga,bhagandara

\section{Abstract}

Bhagandara (fistula in ano) in modern parlance is a common ano rectal condition prevalent in the populations worldwide and its prevalence is second highest after arsha (haemorrhoids). Kshara Sutra is a chief modality in the management of Bhagandara in Ayurvedic science. Exploration of the new plants for the preparation of Kshara as a better substitute of Apamarga Kshara is the need of the hour.

\section{Introduction:-}

In Ayurvedic classics, Bhagandara is considered as one of the Ashta Mahagada. Bhagandara is one of the commonest diseases which occur in ano-rectal region'. The literal meaning of Bhagandara is 'Darana'in Bhaga, guda and vasti Pradesh, which means splitting up or piercing up of perianal region. Acharya Susruta opines that the condition where in, there is tearing or damage of bhaga, guda, vasti region is termed as Bhagandara ${ }^{\text {iii }}$. The condition, in pre-suppurative stage is known as pidaka and suppurative stage is known as Bhagandara.

Bhagandara can be clinically co-related to Fistula-in-ano. It is a communicating tract lined by unhealthy granulation tissue; opens internally in the anal canal or rectum and superficially on the skin around the anus. Fistula-in-ano is a major disease of ano-rectal region and is characterized by persistent pus discharge associated with intermittent pain. If not treated properly gives raise to several complications.

Ayurveda is well known for the treatment of Bhagandara with Kshara Sutra application with negligible rate of recurrence $^{\text {iv }}$. So far, many researches are carried out in different institutions on Bhagandara. Previous research works had been conducted on Madhu Kshara Sutra, Palasha Kshara Sutra, Guggulu Kshara Sutra, Udumbar Ksheera Sutra, Papaya Kshara Sutra, Arka Ksheera Sutra etc, in the management of Bhagandara ${ }^{\mathrm{V}}$

Sushruta, in Kshara Paka Vidhi Adhyaya has mentioned 23 drugs from which Kshara can be prepared ${ }^{\mathrm{vi}}$. Arka is one among Kshara explained in Kshara Paka Vidhi Adhyaya. But so far no research work has been carried out to evaluate the effect of Arka Kshara Sutra in the management of Bhagandara ${ }^{\text {vii }}$.

The standard Apamarga Kshara Sutra is prepared by repeated coatings (11) of Snuhi Ksheera, (7) Apamarga Kshara, and (3) Haridra Churna. The Apamarga Kshara sutra is well proven modality in the management of Bhagandar and has been standardized by the CCRAS. 
Arka is Katu and Tikta in Rasa, Laghu, Ruksha and Teekshna Guna, Ushna Virya and having Bhedana, Krimighna, Vishaghna, Vranahara, Vatahara, Shophahara actions. ${ }^{\text {vii }}$

Though each of the thread had good cutting rates and other preparation advantages they also had some disadvantages.

The acharya Sushruta in Sutrastana Ksharapakavidi adyaya has mentiond 21 drugs can be used for the preparation of Kshara among which Arka is selected in the preparation of Kshara Sutra as Arka is inherited with the properties of Rasa : Katu, Tikta Guna : Laghu, Ruksha, Theekshna Virya : Usna Vipaka : Katu Karma : Bhedana, Deepana, Krimighna, Visaghna, Vranahara, Vatahrit, Sopha,Swasahara. Considering the above problems so, we are in need to find out such a drug which is easily available and equally effective. The idea behind the present work is to find out the effectiveness of Arka Kshara Sutra in the management of Bhagandara and find out such a treatment, which is economical, easily available, as well as minimize the problems of Kshara Sutra therapy ${ }^{\text {ix }}$. It is a comparative study in which 20 subjects were selected in each group to compare the efficacy of Apamarga Kshara Sutra as control group and Arka Kshara Sutra as trial group. The results obtained are given in the present study.

\section{Aims And Objective Of The Study:-}

1. To Screen and review the all available literature from Ayurvedic and contemporary sciences on Bhagandara.

2. Evaluation of the effect of Arka Kshara Sutra in the management Bhagandara.

3. To compare the effect of Arka Kshara Sutra and Apamarga Kshara Sutra in the management of Bhagandara.

\section{Materials and Methods:-}

A clinical study was planned on Arka Kshara Sutra and a clinical trial was done in Dept. of P.G.Studies in Shalyatantra, Parul institute of Ayurveda and hospital, Limda. Management of Fistula-in-Ano with Kshara Sutra therapy has been popularized in this institute for past two decade."A COMPARATIVE CLINICAL STUDY OF ARKA KSHARA SUTRA AND APAMARGA KSHARA SUTRA IN THE MANAGEMENT OF BHAGANDAR(FISTULA IN ANO)" has been studied in 40 cases which is divided into two groups i.e. Controlled group Apamarga Kshara Sutra and trial group Arka Kshara Sutra.

\section{Source Of Data:-}

The patients will be selected from the OPD and IPD department of Shalya Tantra of Parul institute of Ayurveda and hospital, Limda.

\section{Groups Design:-}

Minimum 40 Patients of Bhagandara will be randomly divided into the following two groups.

\section{Group A : Trial group (20 Patients):-}

The patients of this group will be applied Arka Kshara Sutra. The Kshara Sutra will be changed once in a week till a complete cutting of the tract.

\section{Group B:- Standard group (20 Patients):-}

The patients of this group will be applied Apamarga Kshara Sutra as per Classical method. The Kshara Sutra will be changed once in a week till a complete cutting of the tract.

\section{Duration Of The Treatment:-}

It will depend on the length of fistulous tract, which is approximately $1 \mathrm{~cm}$ cutting time of the tract in 7 days as per reported in various studies.

\section{Randomization Method:-}

It is Simple random sampling method

\section{Diagnostic Criteria: -}

- Diagnosis will be made on the basis of Lakshanas of Bhagandara.

- Fistulogram (if necessary) 


\section{Inclusion Criteria:-}

- Clinical signs and symptom of all types of Bhaganadara.

- Patient above 20yrs and below 70 yrs

\section{Exclusion Criteria:-}

- HIV and HBsAg positive patients.

- Uncontrolled Diabetes Mellitus.

- Patients group of ages below 20yrs and above 70yrs.

- Patients who are not ready to sign written informed consent form.

- Secondary fistula due to
a) Ulcerative colitis
b) Chron's disease
c) Tuberculosis
d) Carcinoma of rectum and anal canal.

Preparation of Arka-Kshara Sutra:-

Table 1:- pH of different drugs in Apamarga Kshara Sutra and Arka- Kshara Sutra.

\begin{tabular}{|c|c|c|}
\hline Sl. No. & Drugs & PH \\
\hline 1 & Arka Kshara Sutra & 11.23 \\
& Snuhi & 5.6 \\
& Arka & 13.74 \\
& Haridra & 6.2 \\
\hline 2 & Apamarga Kshara Sutra & 9.7 \\
& Snuhi & 5.6 \\
& Apamarga Kshara & 9.7 \\
& Haridra & 6.2 \\
\hline
\end{tabular}

\section{Assessment Criteria:-}

1. U.C.T. (Unit Cutting Time)

$=$ Total No. of days taken for cut through $=\ldots$.. Days $/$ centimetre

2. Pain Initial length of track in centimetre

3. Discharge

\begin{tabular}{|c|c|c|c|c|}
\hline Sr. No. & \multicolumn{2}{|c|}{ PARAMETER } & CRITERIA & GRADE \\
\hline $\mathbf{2}$ & Subjective & Pain & No pain & 0 \\
& & & Mild pain & $1-3$ \\
& & & Moderate pain & $4-7$ \\
& & & Severe pain & $7-10$ \\
\hline $\mathbf{3}$ & Objective & Discharge & Absent & 0 \\
& & & Present & 1 \\
\hline
\end{tabular}

\section{Grading :}

Pain:-

Grade 0 - No pain

Grade 1 - Mild

Grade 2 - Moderate

Grade 3 - Severe

\section{Discharge:-}

Grade 0-Absent

Grade 1-Present

\section{Application of arka and apamarga-Kshara Sutra:-}

The patient is kept in proper lithotomy position and perianal region was cleaned with antiseptic lotions and draped. Patient is reassured and gloved finger was gently introduced into the rectum. Then a probe was passed through the external opening of fistula. The tip of the probe was forwarded along the path of least resistance and was guided by 
the finger in rectum to reach into the lumen of anal canal through the internal opening and its tip was finally directed to come out of anal orifice. Then a suitable length of Plain surgical linen thread no. 20 was taken and threaded into the eye of probe. Thereafter the probe was pulled out through the anal orifice, to leave the thread behind in the fistulous track. The two ends of the thread were then tied together with a moderate tightness outside the anal canal. This procedure is called primary threading and on second day post-operative day the arka and apamarga-Kshara Sutra application is done.

\section{Change of Kshara Sutra:-}

All patients were instructed to take hot sitz bath before changing the thread. The Kshara Sutra was changed at weekly interval. The thread is tied to the previously applied Kshara Sutra in position towards outer end of the knot. Then an artery forceps is applied inner end to the same knot. Then the old thread is cut between the artery forceps and the knot. Pulling of the artery forceps along with the thread ultimately replaces the old thread by Kshara Sutra. Then the two ends are ligated and bandaging was done. This procedure is done by Railroad technique. The same procedure is followed for successive changes of Kshara Sutra at weekly interval.

\section{Follow-up:-}

All the patients were instructed to visit Ano-rectal clinic once in a week till the complete cut through of the fistulous tract.

\section{Observations and Results:-}

"A COMPARATIVE CLINICAL STUDY OF ARKA KSHARA SUTRA AND APAMARGA KSHARA SUTRA IN THE MANAGEMENT OF BHAGANDAR(FISTULA IN ANO)” have been studied in 39

Cases, attended in Dept. of P.G.Studies in Shalyatantra, parul institute of ayurvedlimda, divided into two groups, control group Apamarga Kshara Sutra was applied, while in trial group Arka Kshara Sutra was applied after establishing the diagnosis of Bhagandara. All 40 patients of Bhagandara have been analysied for age, sex, habitat, socio-economic status, doshicprakriti, type of Bhagandara, type of fistula, chronicity of disease, position of external openings, length of the fistulous track, clinical findings, unit cutting time etc were observed and noted. The Unit cutting time means the time taken by Kshara Sutra to cut one $\mathrm{cm}$ of fistulous track in days. This was calculated using the formula.

U.C.T. $=$ Total number of days taken for cut through $=\ldots$ days $/ \mathrm{cm}$

$$
\text { Initial length of track in cms }
$$

\section{Age Incidence:-}

The distributions of 40 patients were youngest patient was 21 years and eldest patient was 65 years. The incidence of Bhagandara is maximum in age group of 22-40 years and I minimum in age group of 40-70.

\begin{tabular}{|l|l|l|l|l|}
\hline group & age & Frequency & Percentage & Cumulative Percent \\
\hline Group A & $<=40$ Yrs & 12 & $60 \%$ & $60 \%$ \\
& $>40$ Yrs & 08 & $40 \%$ & $40 \%$ \\
\hline Total & & 20 & $100 \%$ & $\%$ \\
\hline Group B & $<=40$ Yrs & 12 & $63.2 \%$ & $63.2 \%$ \\
& $>40$ Yrs & 07 & $36.8 \%$ & $36.8 \%$ \\
\hline total & 19 & $100 \%$ & $100 \%$ \\
\hline
\end{tabular}




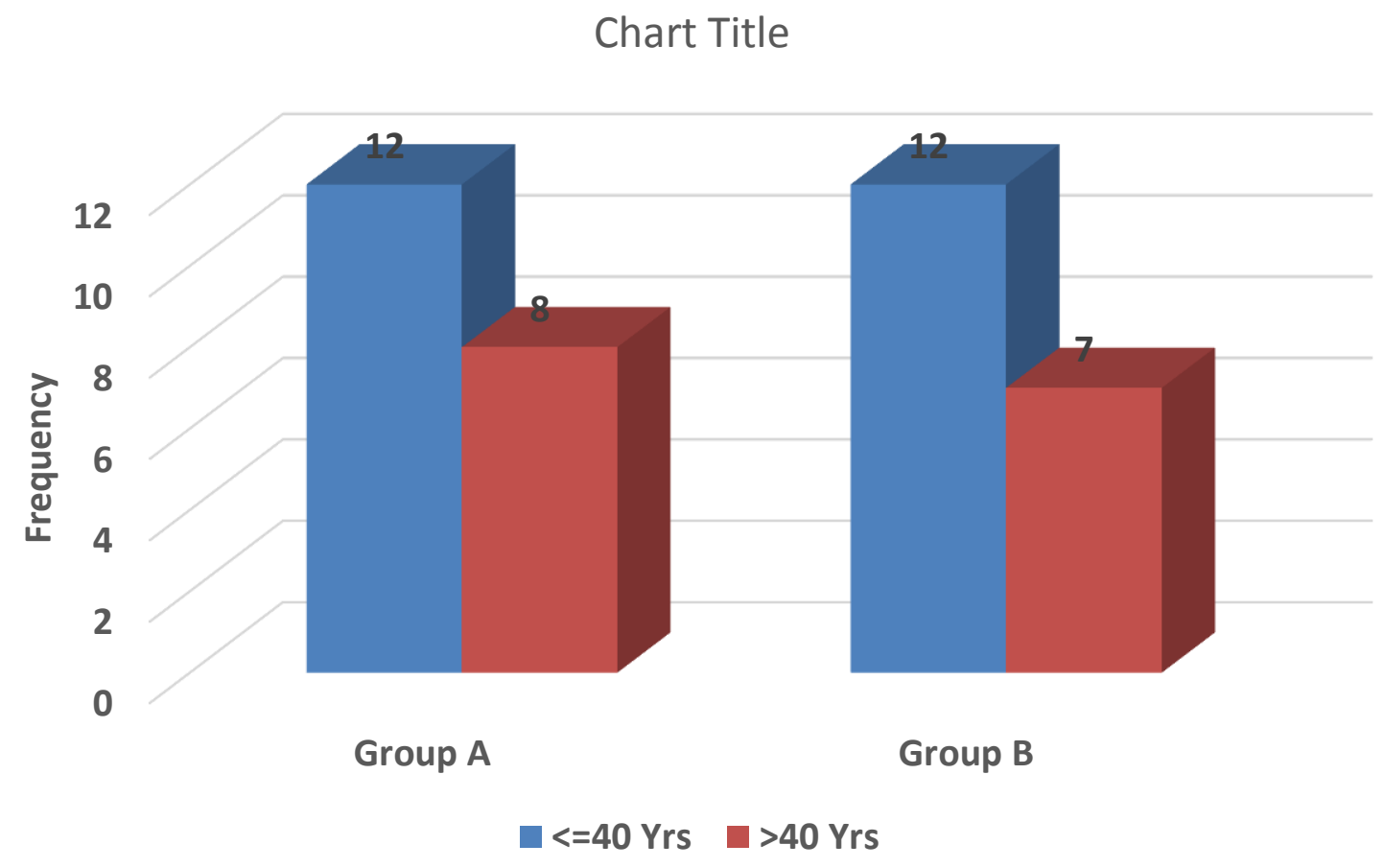

\section{Gender Incidence:-}

Out of 39 cases there were 33 male patients and 06 were female patients. This analysis shows males are more prone to Bhagandara than females.

\begin{tabular}{|l|l|l|l|l|l|l|}
\hline \multicolumn{2}{|l|}{ SEX } & Frequency & Percent & Valid Percent & $\begin{array}{l}\text { Cumulative } \\
\text { Percent }\end{array}$ \\
\hline Group & Valid & F & 3 & 15.0 & 15.0 & 15.0 \\
\cline { 3 - 7 } & & M & 17 & 85.0 & 85.0 & 100.0 \\
\cline { 3 - 7 } & Total & 20 & 100.0 & 100.0 & \\
\hline \multirow{3}{*}{ Group B } & Valid & F & 3 & 15.8 & 15.8 & 15.8 \\
\cline { 3 - 7 } & M & 16 & 84.2 & 84.2 & 100.0 \\
\cline { 3 - 7 } & Total & 19 & 100.0 & 100.0 & \\
\hline
\end{tabular}




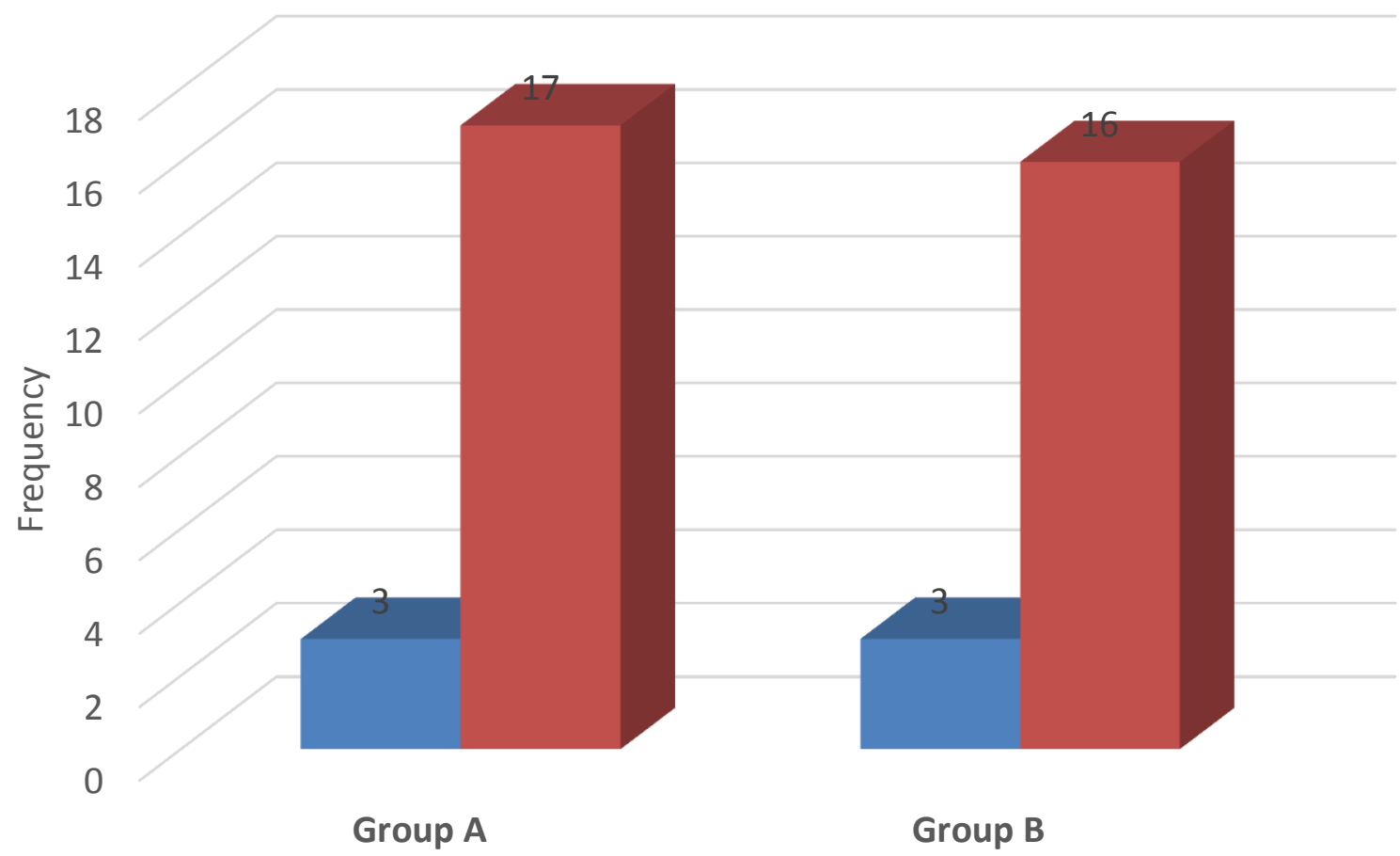

Female Male

\section{Religion:-}

Cases were analyzed in view of their religion, out of 39 cases 34 cases were Hindus, 5 Cases wereMusllim.

\begin{tabular}{|c|c|c|c|c|c|c|}
\hline \multicolumn{7}{|c|}{ RELIGION } \\
\hline Group & & & Frequency & Percent & Valid Percent & $\begin{array}{l}\text { Cumulative } \\
\text { Percent }\end{array}$ \\
\hline \multirow[t]{3}{*}{ Group A } & \multirow[t]{3}{*}{ Valid } & HINDU & 16 & 80.0 & 80.0 & 80.0 \\
\hline & & MUSLIM & 4 & 20.0 & 20.0 & 100.0 \\
\hline & & Total & 20 & 100.0 & 100.0 & \\
\hline \multirow[t]{3}{*}{ Group B } & \multirow[t]{3}{*}{ Valid } & HINDU & 18 & 94.7 & 94.7 & 94.7 \\
\hline & & MUSLIM & 1 & 5.3 & 5.3 & 100.0 \\
\hline & & Total & 19 & 100.0 & 100.0 & \\
\hline
\end{tabular}




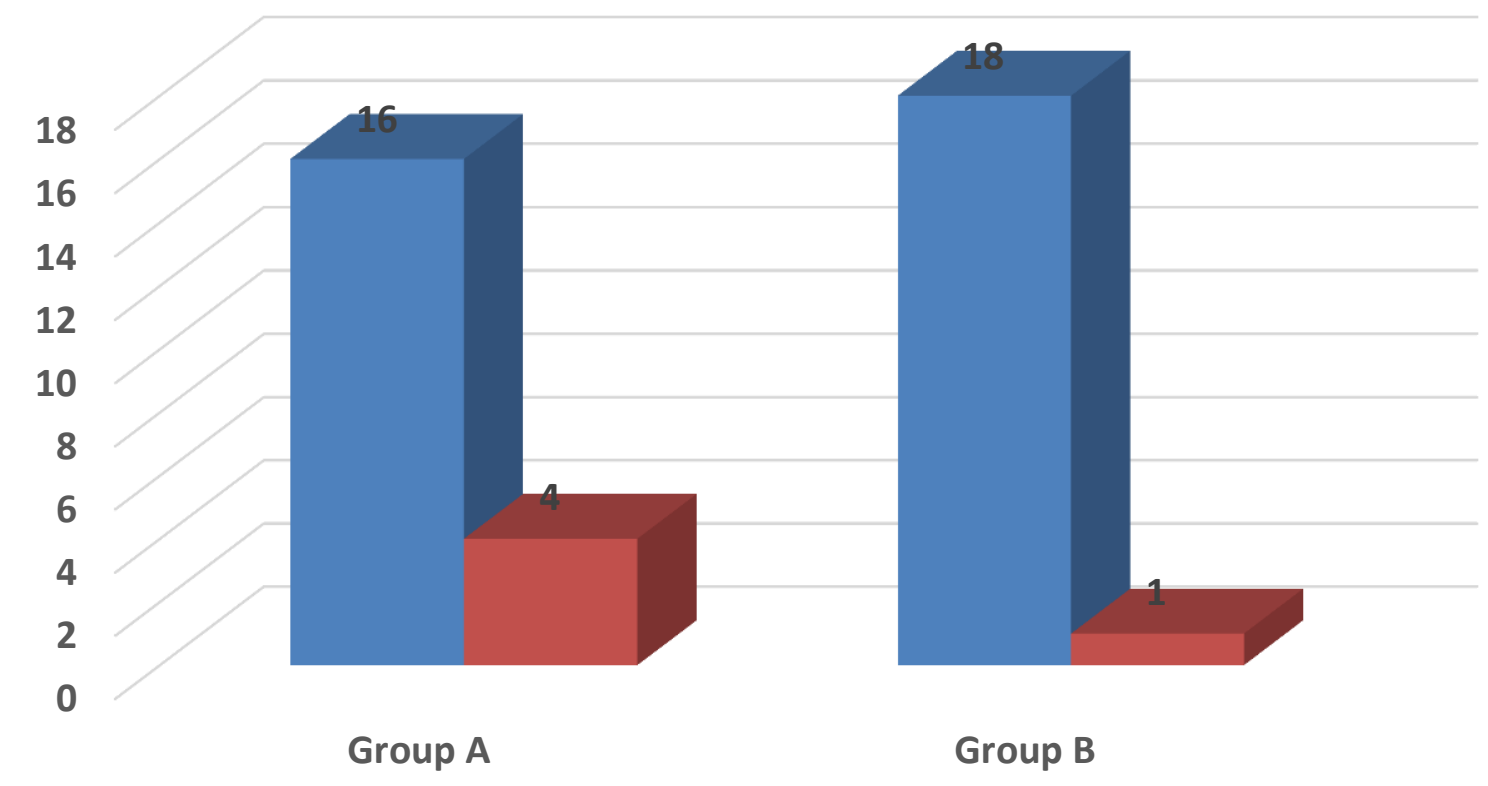

Hindu Muslim

Socio-Economic Status:-

Analysis of socio-economic status of 39 cases of fistula reveals that majority of patientsbelonged to middle class( 22 cases) whereas patients were found in lower class(17 cases) status.

\begin{tabular}{|c|c|c|c|c|c|c|}
\hline \multicolumn{7}{|c|}{ SOCIO-ECONOMIC status } \\
\hline \multicolumn{3}{|c|}{ Group } & Frequency & Percent & Valid Percent & Cumulative \\
\hline \multirow[t]{3}{*}{ Group A } & \multirow[t]{3}{*}{ Valid } & LOW & 11 & 55.0 & 55.0 & 55.0 \\
\hline & & MIDDLE & 9 & 45.0 & 45.0 & 100.0 \\
\hline & & Total & 20 & 100.0 & 100.0 & \\
\hline \multirow[t]{3}{*}{ Group B } & \multirow[t]{3}{*}{ Valid } & LOW & 6 & 31.6 & 31.6 & 31.6 \\
\hline & & MIDDLE & 13 & 68.4 & 68.4 & 100.0 \\
\hline & & Total & 19 & 100.0 & 100.0 & \\
\hline
\end{tabular}




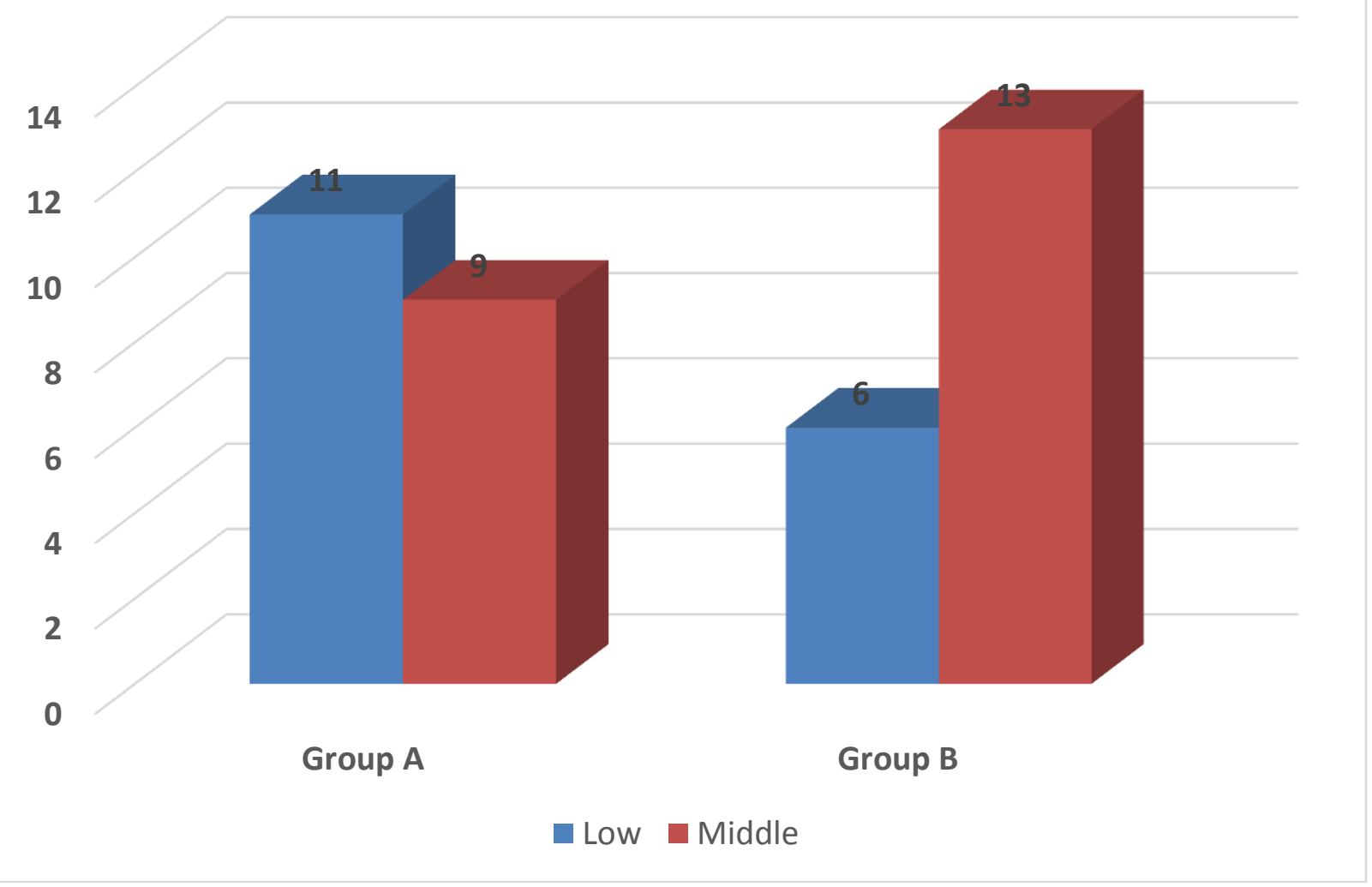

\section{Nature of work:-}

Many scientific workers considered nature of work as one of the major contributing factors in development of fistula-in-ano. The cases in the present study were divided three categories according to their nature of work. a)Sedentary - persons sitting more than six hours with less physical activity in a day eg. Businessman, Clerks, Professors, etc.

b)Moderate - who were working or touring more than 6 hours in a day eg. Students, Housewives, etc. c)Strenuous - who were undergoing in vigorous physical activities eg. Labour, Farmers, Carpenters, Mechanics, etc

\begin{tabular}{|c|c|c|c|c|c|c|}
\hline \multicolumn{7}{|c|}{ NATURE OF work } \\
\hline \multicolumn{3}{|c|}{ Group } & Frequency & Percent & Valid Percent & Cumulative \\
\hline \multirow[t]{4}{*}{ Group A } & \multirow[t]{4}{*}{ Valid } & MODERATE & 8 & 40.0 & 40.0 & 40.0 \\
\hline & & SEDENTARY & 3 & 15.0 & 15.0 & 55.0 \\
\hline & & STRENOUS & 9 & 45.0 & 45.0 & 100.0 \\
\hline & & Total & 20 & 100.0 & 100.0 & \\
\hline \multirow[t]{3}{*}{ Group B } & \multirow[t]{3}{*}{ Valid } & MODERATE & 12 & 63.2 & 63.2 & 63.2 \\
\hline & & STRENOUS & 7 & 36.8 & 36.8 & 100.0 \\
\hline & & Total & 19 & 100.0 & 100.0 & \\
\hline
\end{tabular}




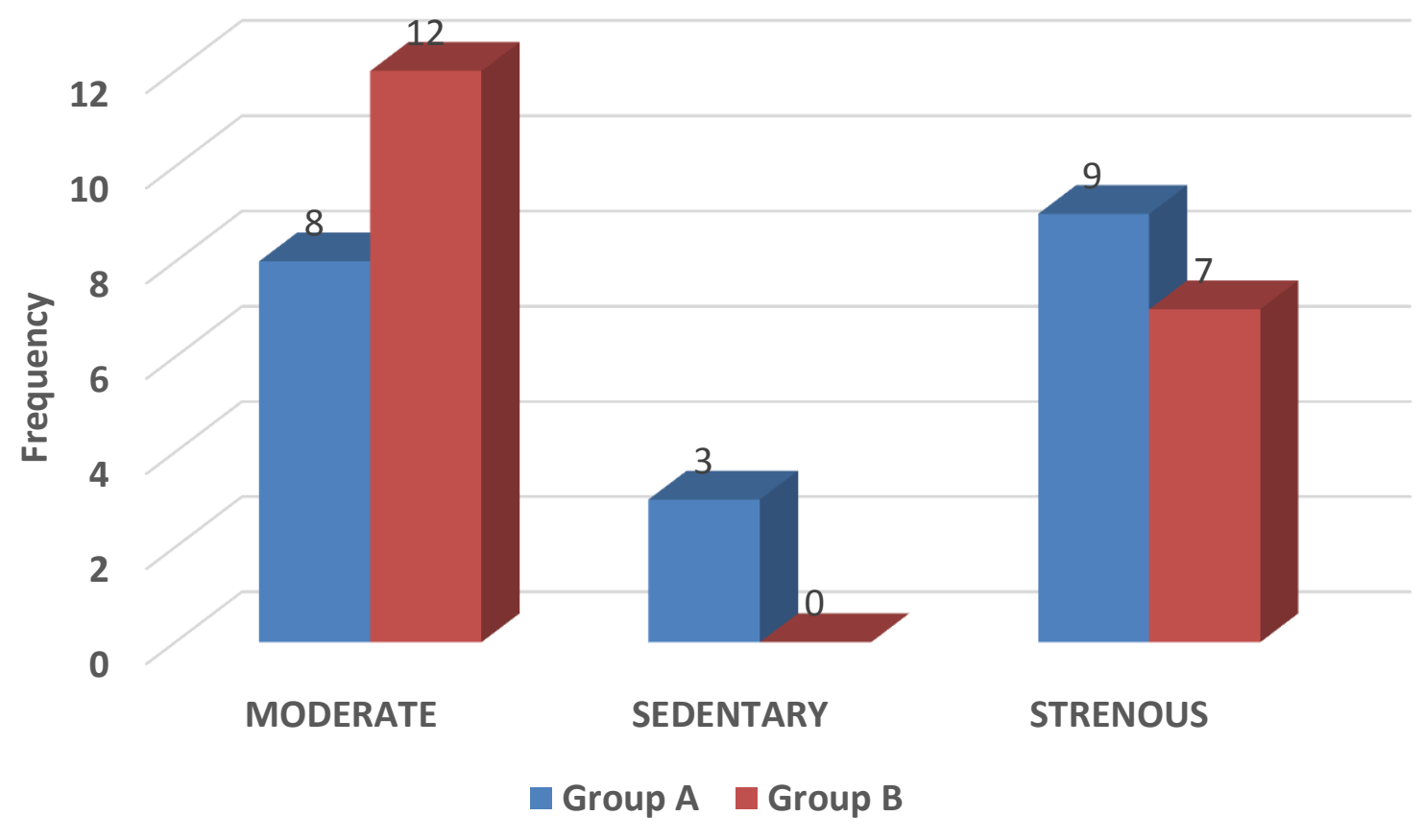

Occupation:-

\begin{tabular}{|c|c|c|c|c|c|c|}
\hline \multicolumn{7}{|c|}{ OCCUPATION } \\
\hline \multicolumn{3}{|l|}{ Group } & Frequency & Percent & Valid Percent & Cumulative Percent \\
\hline \multirow[t]{5}{*}{ Group A } & \multirow[t]{5}{*}{ Valid } & HOUSEWIFE & 3 & 15.0 & 15.0 & 15.0 \\
\hline & & LABOUR & 10 & 50.0 & 50.0 & 65.0 \\
\hline & & SERVICE & 6 & 30.0 & 30.0 & 95.0 \\
\hline & & STUDENT & 1 & 5.0 & 5.0 & 100.0 \\
\hline & & Total & 20 & 100.0 & 100.0 & \\
\hline \multirow[t]{5}{*}{ Group B } & \multirow[t]{5}{*}{ Valid } & HOUSEWIFE & 3 & 15.8 & 15.8 & 15.8 \\
\hline & & LABOUR & 6 & 31.6 & 31.6 & 47.4 \\
\hline & & SERVICE & 8 & 42.1 & 42.1 & 89.5 \\
\hline & & STUDENT & 2 & 10.5 & 10.5 & 100.0 \\
\hline & & Total & 19 & 100.0 & 100.0 & \\
\hline
\end{tabular}




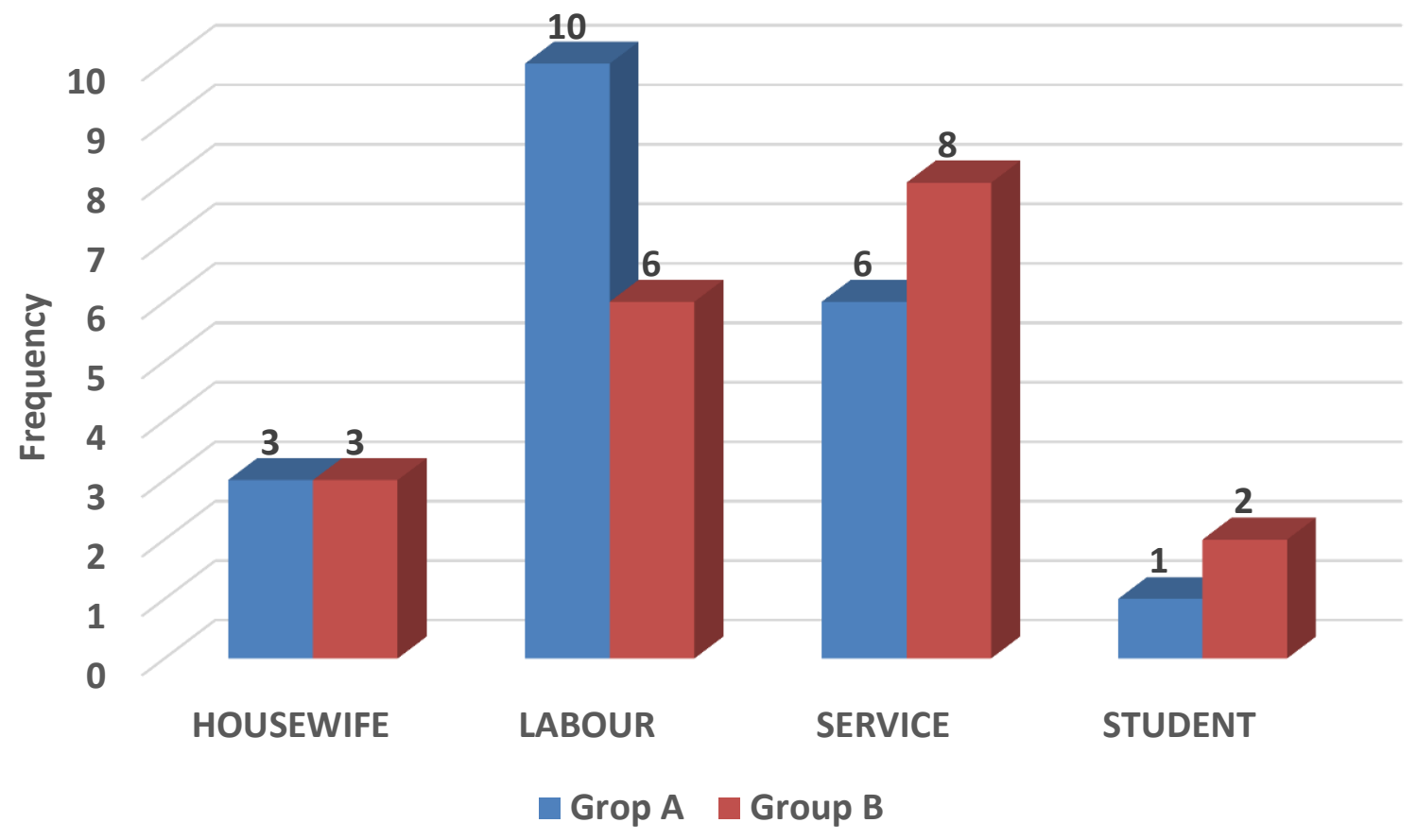

\section{Nature of Diet:-}

While observing the nature of diet, it was found that non-vegetarian patients (72\%) were majority in number than the patients who were on vegetarian diet (28\%).

\begin{tabular}{|c|c|c|c|c|c|c|}
\hline \multicolumn{7}{|l|}{ DIET } \\
\hline \multicolumn{3}{|l|}{ Group } & Frequency & Percent & Valid Percent & $\begin{array}{l}\text { Cumulative } \\
\text { Percent }\end{array}$ \\
\hline \multirow[t]{3}{*}{ Group A } & \multirow[t]{3}{*}{ Valid } & MIX & 16 & 80.0 & 80.0 & 80.0 \\
\hline & & VEG & 4 & 20.0 & 20.0 & 100.0 \\
\hline & & Total & 20 & 100.0 & 100.0 & \\
\hline \multirow[t]{3}{*}{ Group B } & \multirow[t]{3}{*}{ Valid } & MIX & 12 & 63.2 & 63.2 & 63.2 \\
\hline & & VEG & 7 & 36.8 & 36.8 & 100.0 \\
\hline & & Total & 19 & 100.0 & 100.0 & \\
\hline
\end{tabular}




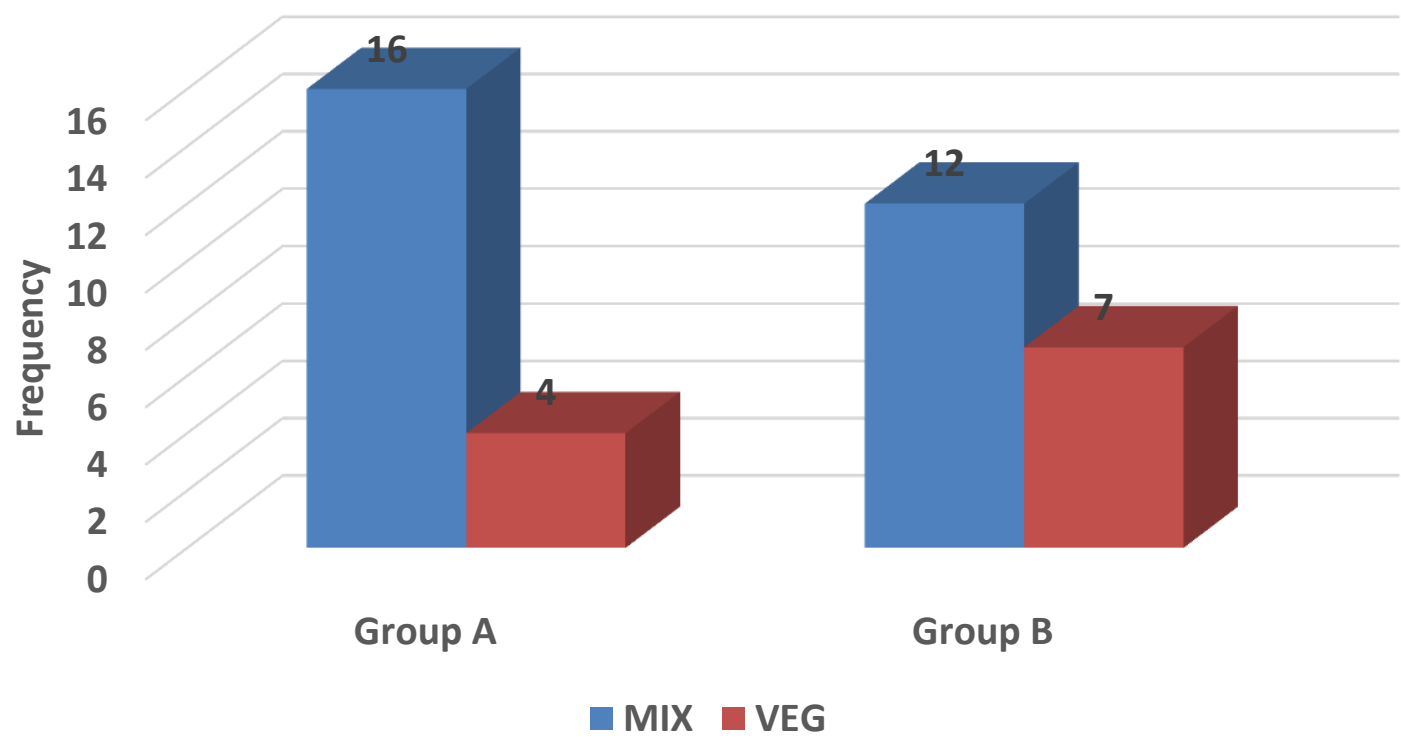

Nature of bowel habits:-

In the present study nature of bowel habits were broadly classified into 2 groups. The maximum numbers were found with 26 cases constipated, 13 cases irregular we found.

\begin{tabular}{|c|c|c|c|c|c|c|}
\hline \\
\hline Group & & & Frequency & Percent & Valid Percent & $\begin{array}{l}\text { Cumulative } \\
\text { Percent }\end{array}$ \\
\hline \multirow[t]{3}{*}{ Group A } & \multirow[t]{3}{*}{ Valid } & CONSTIPATED & 13 & 65.0 & 65.0 & 65.0 \\
\hline & & IREGULAR & 7 & 35.0 & 35.0 & 100.0 \\
\hline & & Total & 20 & 100.0 & 100.0 & \\
\hline \multirow[t]{3}{*}{ Group B } & \multirow[t]{3}{*}{ Valid } & CONSTIPATED & 13 & 68.4 & 68.4 & 68.4 \\
\hline & & IREGULAR & 6 & 31.6 & 31.6 & 100.0 \\
\hline & & Total & 19 & 100.0 & 100.0 & \\
\hline
\end{tabular}




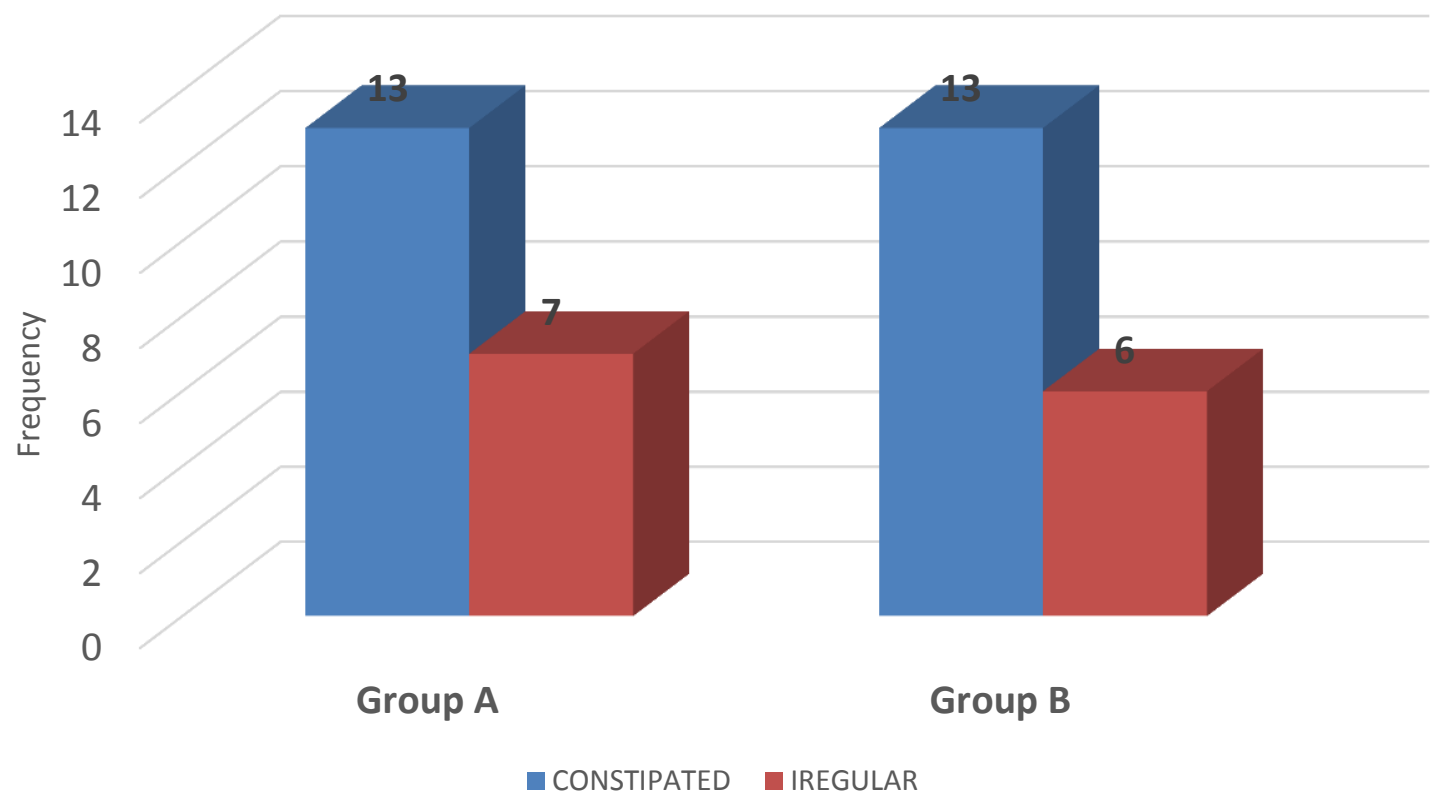

Type of Bhagandara:-

Types of Bhagandara were considered on the basis of description of Sushruta and Vagbhata, out of 39 cases maximum number of patients (70\%) were reported under Parisravi Bhagandara.

\begin{tabular}{|c|c|c|c|c|c|c|}
\hline \multicolumn{7}{|c|}{ TYPES OF BHAGANDAR } \\
\hline \multicolumn{3}{|c|}{ Group } & Frequency & Percent & Valid Percent & $\begin{array}{l}\text { Cumulative } \\
\text { Percent }\end{array}$ \\
\hline \multirow[t]{4}{*}{ Group A } & \multirow[t]{4}{*}{ Valid } & PARISRAVI & 15 & 75.0 & 75.0 & 75.0 \\
\hline & & SHATPONAK & 3 & 15.0 & 15.0 & 90.0 \\
\hline & & USTAGRIV & 2 & 10.0 & 10.0 & 100.0 \\
\hline & & Total & 20 & 100.0 & 100.0 & \\
\hline \multirow[t]{5}{*}{ Group B } & \multirow[t]{5}{*}{ Valid } & ARSHBHAGANDAR & 1 & 5.3 & 5.3 & 5.3 \\
\hline & & PARISRAVI & 16 & 84.2 & 84.2 & 89.5 \\
\hline & & SHATPONAK & 1 & 5.3 & 5.3 & 94.7 \\
\hline & & USTAGRIV & 1 & 5.3 & 5.3 & 100.0 \\
\hline & & Total & 19 & 100.0 & 100.0 & \\
\hline
\end{tabular}




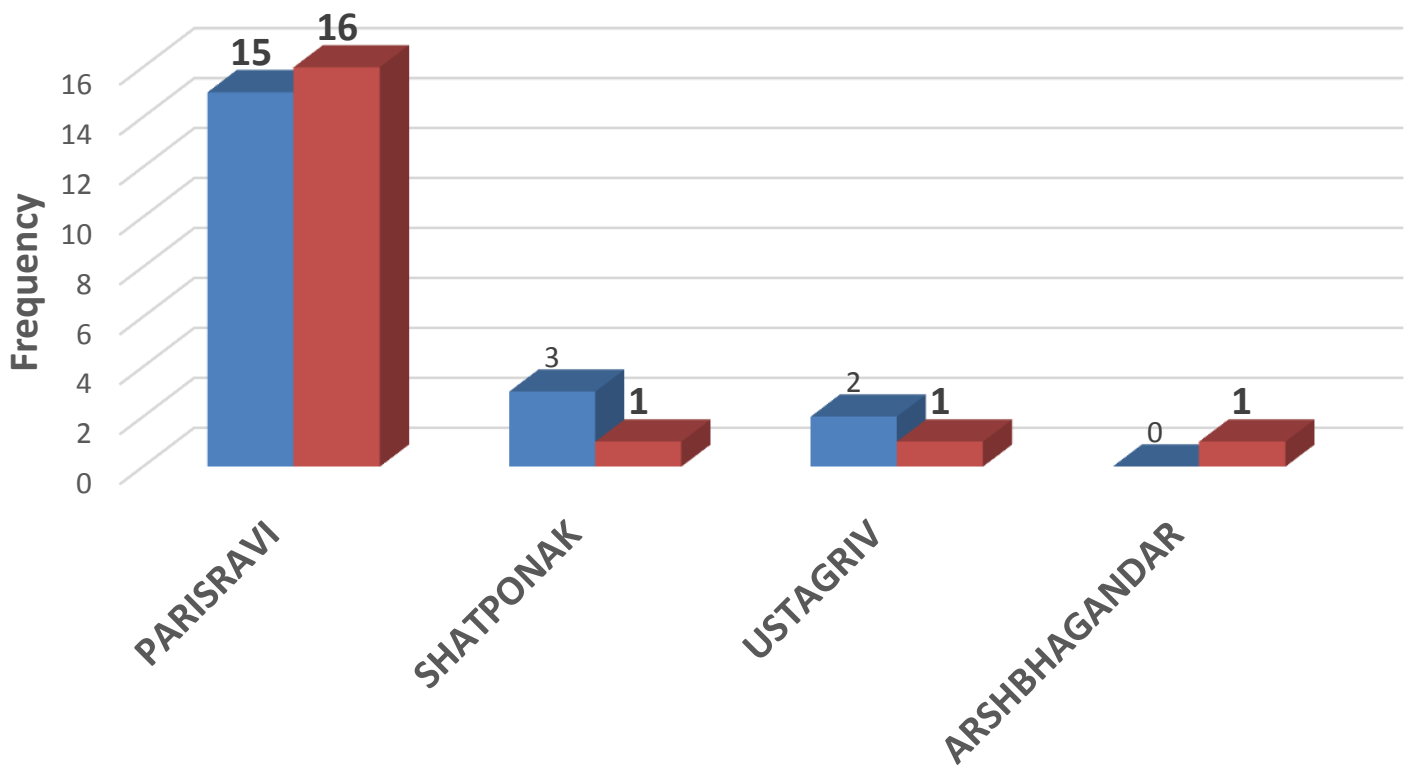

Group A Group B

\begin{tabular}{|c|c|c|c|c|c|c|}
\hline \multicolumn{7}{|c|}{ ADDICTION } \\
\hline \multicolumn{3}{|l|}{ Group } & Frequency & Percent & Valid Percent & $\begin{array}{l}\text { Cumulative } \\
\text { Percent }\end{array}$ \\
\hline \multirow[t]{5}{*}{ Group A } & \multirow[t]{5}{*}{ Valid } & DRINKING & 1 & 5.0 & 5.0 & 5.0 \\
\hline & & NONE & 8 & 40.0 & 40.0 & 45.0 \\
\hline & & SMOKING & 5 & 25.0 & 25.0 & 70.0 \\
\hline & & TOBBACO & 6 & 30.0 & 30.0 & 100.0 \\
\hline & & Total & 20 & 100.0 & 100.0 & \\
\hline \multirow[t]{5}{*}{ Group B } & \multirow[t]{5}{*}{ Valid } & DRINKING & 1 & 5.3 & 5.3 & 5.3 \\
\hline & & NONE & 9 & 47.4 & 47.4 & 52.6 \\
\hline & & SMOKING & 5 & 26.3 & 26.3 & 78.9 \\
\hline & & TOBBACO & 4 & 21.1 & 21.1 & 100.0 \\
\hline & & Total & 19 & 100.0 & 100.0 & \\
\hline
\end{tabular}




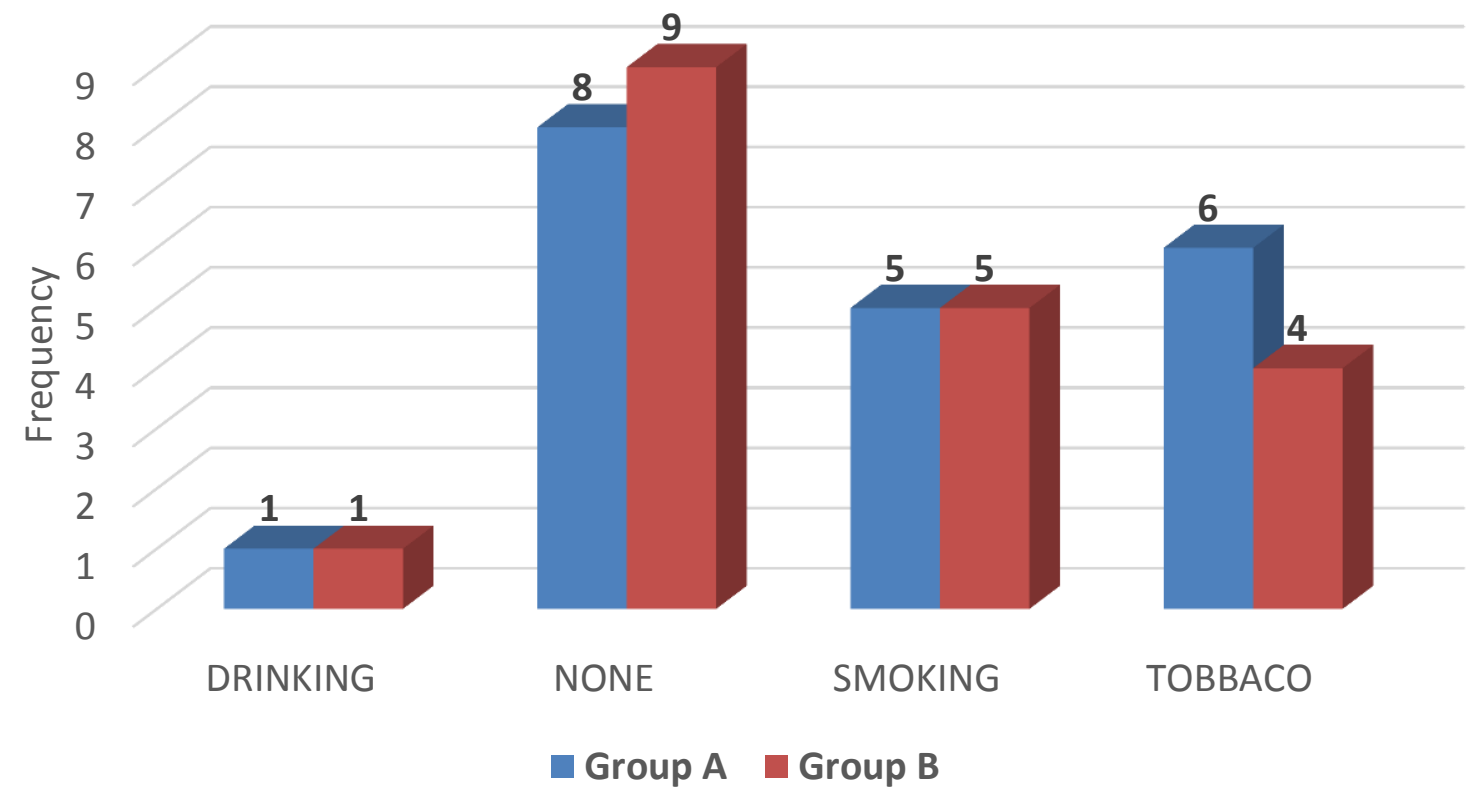

\begin{tabular}{|c|c|c|c|c|c|c|}
\hline \multicolumn{7}{|c|}{ TYPES OF FISTULA } \\
\hline \multicolumn{3}{|l|}{ Group } & Frequency & Percent & Valid Percent & $\begin{array}{l}\text { Cumulative } \\
\text { Percent }\end{array}$ \\
\hline \multirow[t]{4}{*}{ Group A } & \multirow[t]{4}{*}{ Valid } & INTERSPHINCTER & 12 & 60.0 & 60.0 & 60.0 \\
\hline & & SUBCUTANEOUS & 7 & 35.0 & 35.0 & 95.0 \\
\hline & & TRANSPHINCTER & 1 & 5.0 & 5.0 & 100.0 \\
\hline & & Total & 20 & 100.0 & 100.0 & \\
\hline \multirow[t]{5}{*}{ Group B } & \multirow[t]{5}{*}{ Valid } & INTERSPHINCTER & 13 & 68.4 & 68.4 & 68.4 \\
\hline & & SUBCUTANEOUS & 2 & 10.5 & 10.5 & 78.9 \\
\hline & & SUBMUCOSAL & 1 & 5.3 & 5.3 & 84.2 \\
\hline & & TRANSPHINCTER & 3 & 15.8 & 15.8 & 100.0 \\
\hline & & Total & 19 & 100.0 & 100.0 & \\
\hline
\end{tabular}




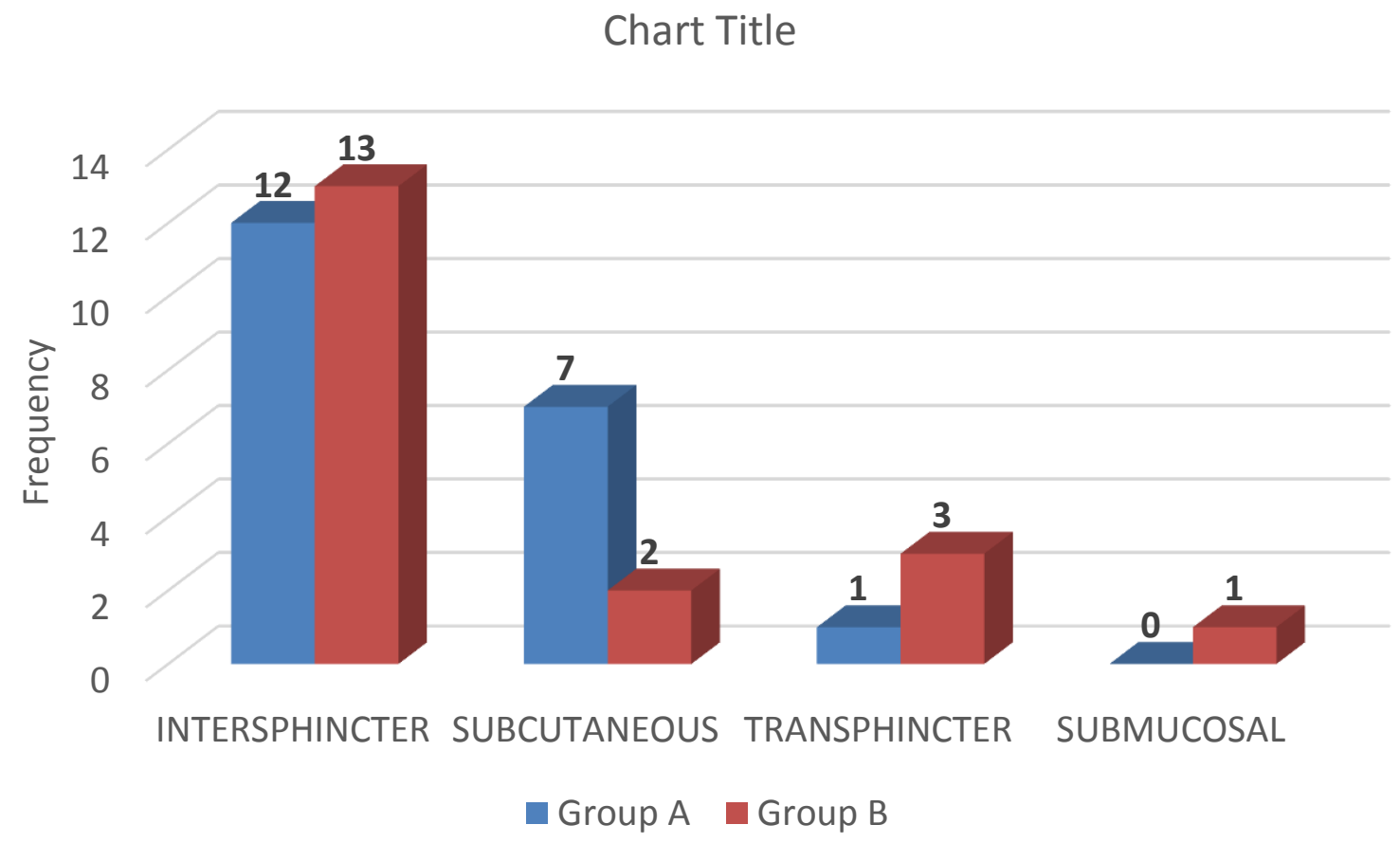

Number of External openings:-

Analyses of 39 cases were done in terms of number of external fistulous openings.

33 cases (85\%) were having single external fistulous opening, while 3 cases $(5 \%)$ was having two openings. 3 cases $(5 \%)$ having three opening.

\begin{tabular}{|c|c|c|c|c|c|c|}
\hline \multicolumn{7}{|c|}{ NO.OF EXTERNAL OPENING } \\
\hline \multicolumn{3}{|c|}{ Group } & Frequency & Percent & Valid Percent & Cumulative \\
\hline \multirow[t]{4}{*}{ Group A } & \multirow[t]{4}{*}{ Valid } & 1.0 & 16 & 80.0 & 80.0 & 80.0 \\
\hline & & 2.0 & 2 & 10.0 & 10.0 & 90.0 \\
\hline & & 3.0 & 2 & 10.0 & 10.0 & 100.0 \\
\hline & & Total & 20 & 100.0 & 100.0 & \\
\hline \multirow[t]{4}{*}{ Group B } & \multirow[t]{4}{*}{ Valid } & 1.0 & 17 & 89.5 & 89.5 & 89.5 \\
\hline & & 2.0 & 1 & 5.3 & 5.3 & 94.7 \\
\hline & & 3.0 & 1 & 5.3 & 5.3 & 100.0 \\
\hline & & Total & 19 & 100.0 & 100.0 & \\
\hline
\end{tabular}




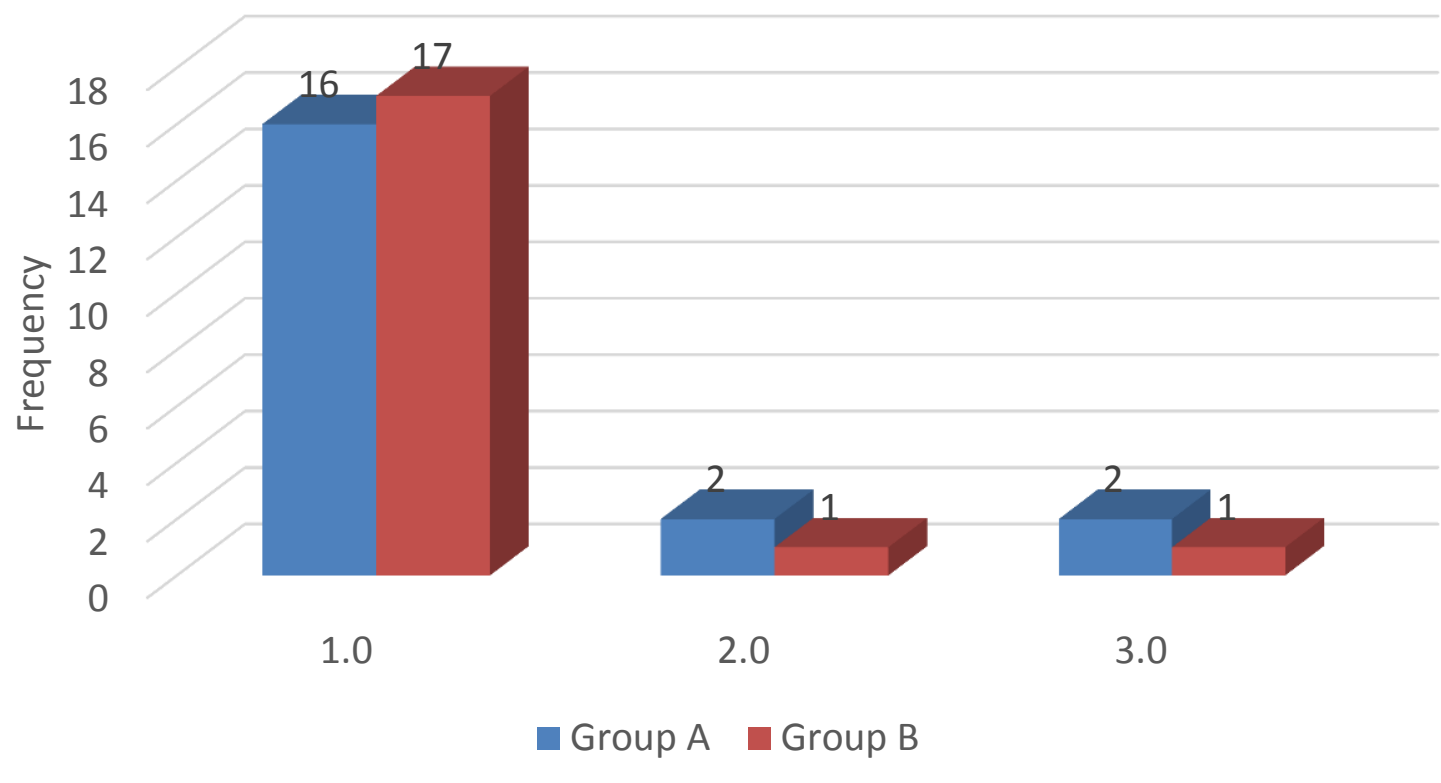

Level of fistula:-

- Analysis of 39 patients of level of Fistula-in-ano was made. The maximum 95\% patient were suffering from low anal fistula and 5\% high anal fistula.

\begin{tabular}{|c|c|c|c|c|c|c|}
\hline \multicolumn{7}{|c|}{ LEVEL OF FISTULA } \\
\hline \multicolumn{3}{|c|}{ Group } & Frequency & Percent & Valid Percent & Cumulative Percent \\
\hline \multirow[t]{3}{*}{ Group A } & \multirow[t]{3}{*}{ Valid } & HIGH & 1 & 5.0 & 5.0 & 5.0 \\
\hline & & LOW & 19 & 95.0 & 95.0 & 100.0 \\
\hline & & Total & 20 & 100.0 & 100.0 & \\
\hline \multirow[t]{3}{*}{ Group B } & \multirow[t]{3}{*}{ Valid } & HIGH & 1 & 5.3 & 5.3 & 5.3 \\
\hline & & LOW & 18 & 94.7 & 94.7 & 100.0 \\
\hline & & Total & 19 & 100.0 & 100.0 & \\
\hline
\end{tabular}




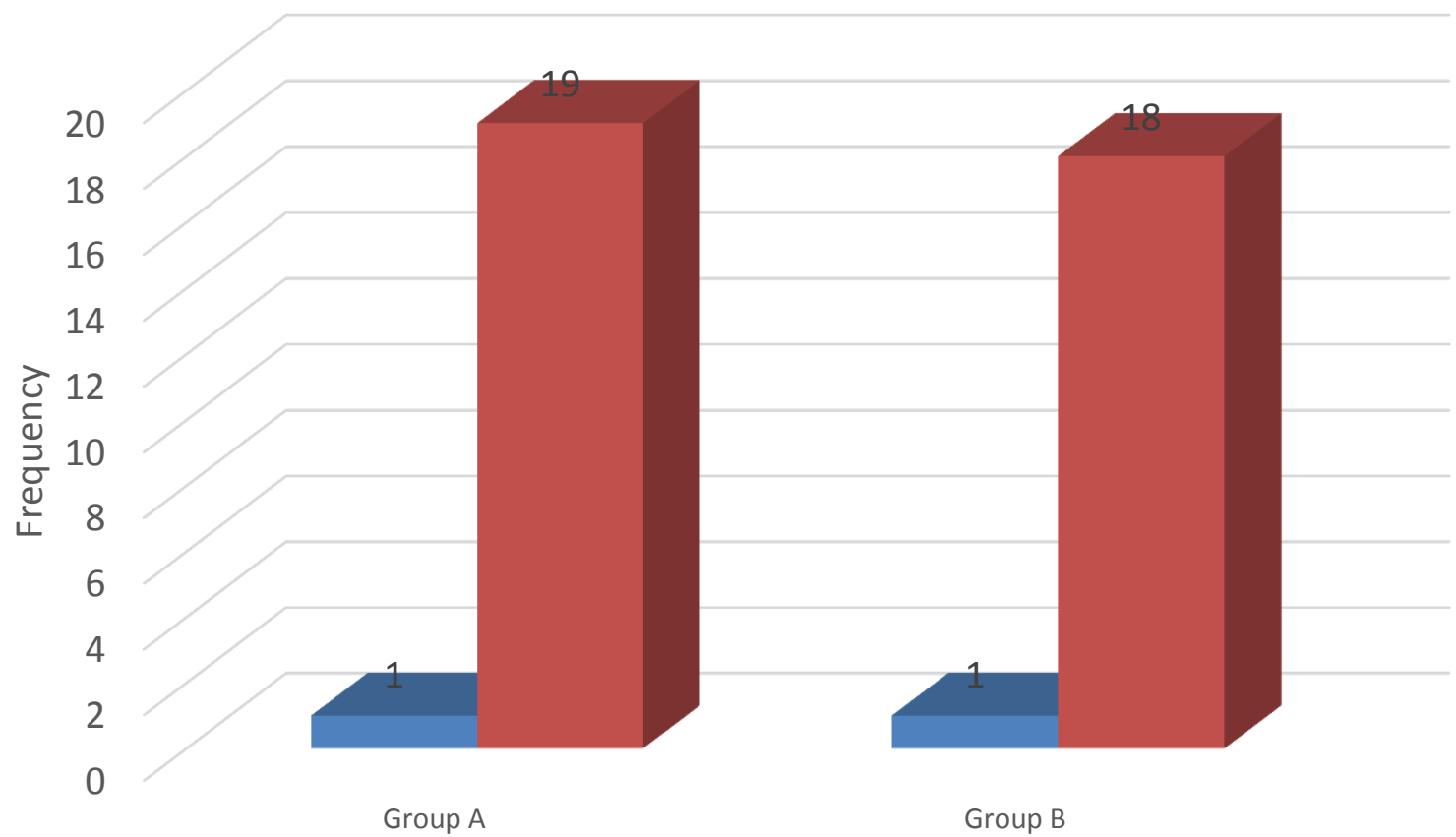

HIGH $\square$ LOW

Types of fistulous track on Probing:-

\begin{tabular}{|c|c|c|c|c|c|c|}
\hline \multicolumn{7}{|c|}{ TYPES OF FISTULA } \\
\hline \multicolumn{3}{|c|}{ Group } & Frequency & Percent & Valid Percent & Cumulative \\
\hline \multirow[t]{4}{*}{ Group A } & \multirow{4}{*}{ Valid } & COMPLETE & 14 & 70.0 & 70.0 & 70.0 \\
\hline & & CURVED & 5 & 25.0 & 25.0 & 95.0 \\
\hline & & RADIAL & 1 & 5.0 & 5.0 & 100.0 \\
\hline & & Total & 20 & 100.0 & 100.0 & \\
\hline \multirow[t]{3}{*}{ Group B } & \multirow[t]{3}{*}{ Valid } & COMPLETE & 15 & 78.9 & 78.9 & 78.9 \\
\hline & & CURVED & 4 & 21.1 & 21.1 & 100.0 \\
\hline & & Total & 19 & 100.0 & 100.0 & \\
\hline
\end{tabular}




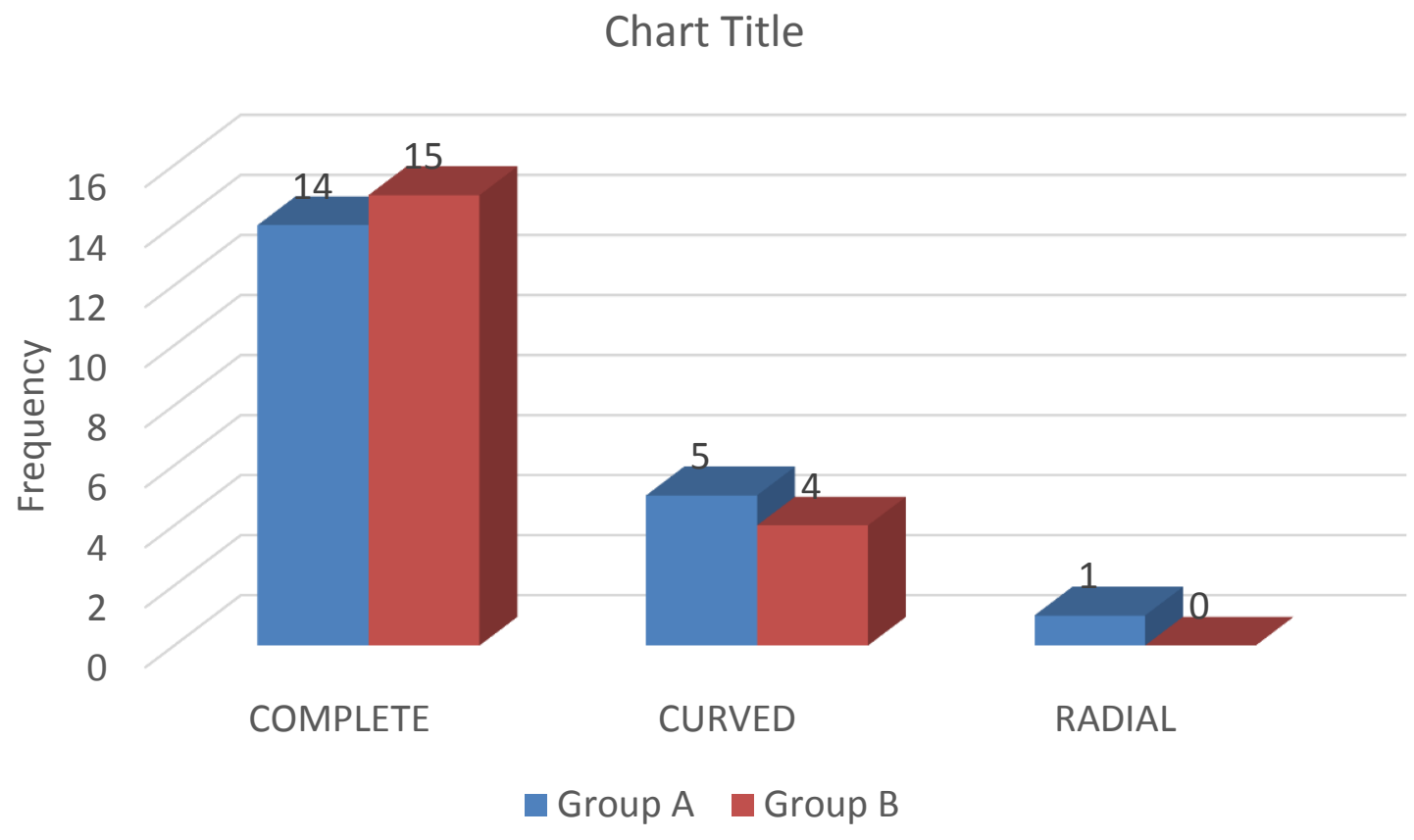

\section{Previous Surgery:-}

Patients were classified into two groups on the basis of surgical treatment reported (recurrent) and non-operated (fresh) cases. Out of 39 cases all cases were reported as non operated cases(fistula in ano) out of this one patient was operated for fistula in ano procedure.

\begin{tabular}{|c|c|c|c|c|c|c|}
\hline \multicolumn{7}{|c|}{ PREVIOUS SURGERY } \\
\hline \multicolumn{3}{|l|}{ Group } & Frequency & Percent & Valid Percent & $\begin{array}{l}\text { Cumulative } \\
\text { Percent }\end{array}$ \\
\hline \multirow[t]{3}{*}{ Group A } & \multirow[t]{3}{*}{ Valid } & $\mathrm{NO}$ & 19 & 95.0 & 95.0 & 95.0 \\
\hline & & YES & 1 & 5.0 & 5.0 & 100.0 \\
\hline & & Total & 20 & 100.0 & 100.0 & \\
\hline Group B & Valid & NO & 19 & 100.0 & 100.0 & 100.0 \\
\hline
\end{tabular}

Incidence of Anaesthesia in application of Primary threading:-

Out of 39 patients, maximum number of 37 cases (95\%) having applied primary threading with local Anesthesia,5\% in spinal

\begin{tabular}{|c|c|c|c|c|c|c|}
\hline \multicolumn{7}{|c|}{ INCIDENCE OF ANESTHESIA } \\
\hline \multicolumn{3}{|c|}{ Group } & Frequency & Percent & Valid Percent & $\begin{array}{l}\text { Cumulative } \\
\text { Percent }\end{array}$ \\
\hline \multirow[t]{3}{*}{ Group A } & \multirow[t]{3}{*}{ Valid } & LOCAL & 19 & 95.0 & 95.0 & 95.0 \\
\hline & & SPINAL & 1 & 5.0 & 5.0 & 100.0 \\
\hline & & Total & 20 & 100.0 & 100.0 & \\
\hline \multirow[t]{3}{*}{ Group B } & \multirow[t]{3}{*}{ Valid } & LOCAL & 18 & 94.7 & 94.7 & 94.7 \\
\hline & & SPINAL & 1 & 5.3 & 5.3 & 100.0 \\
\hline & & Total & 19 & 100.0 & 100.0 & \\
\hline \multicolumn{7}{|c|}{$\begin{array}{l}\text { Incidence of Associated Lesions : } \\
\text { Out of } 39 \text { cases, } 1 \text { case suffering with haemorroids . No cases were observed in prolapse and } \\
\text { malignancy } \\
\text { INCIDENCE OF ASSOCIATED LESION }\end{array}$} \\
\hline \multicolumn{3}{|l|}{ Group } & Frequency & Percent & Valid Percent & $\begin{array}{l}\text { Cumulative } \\
\text { Percent }\end{array}$ \\
\hline
\end{tabular}




\begin{tabular}{|l|l|l|l|l|l|l|}
\hline Group A & \multirow{2}{*}{ Valid } & NO & 19 & 95.0 & 95.0 & 95.0 \\
\cline { 3 - 7 } & & PILES & 1 & 5.0 & 5.0 & 100.0 \\
\cline { 3 - 7 } & & Total & 20 & 100.0 & 100.0 & \\
\hline Group B & Valid & NO & 19 & 100.0 & 100.0 & 100.0 \\
\hline
\end{tabular}

Average Unit cutting time in days/cm in trial and control Groups:-

\begin{tabular}{|c|c|c|c|c|}
\hline Descriptives & & & & \\
\hline & Group A & Group B & Man Whitney & P Values \\
\hline BMI & $20.16 \pm 2.99$ & $20.20 \pm 4.10$ & 169.5 & 0.569 \\
\hline AGE & $37.89 \pm 11.39$ & $39.00 \pm 8.77$ & 184 & 0.879 \\
\hline $\begin{array}{c}\text { Unit Cutting } \\
\text { Time }\end{array}$ & $6.72 \pm 1.81$ & $8.07 \pm 0.59$ & 55 & $<0.001$ \\
\hline Diff. in Burning & $0.63 \pm 0.49$ & $0.5 \pm 0.51$ & 165 & 0.496 \\
\hline Diff in Pain & $1.63 \pm 0.68$ & $1.40 \pm 0.68$ & 158.5 & 0.38 \\
\hline
\end{tabular}

\begin{tabular}{|l|r|l|l|l|}
\hline Unit cutting time & N & Mean & SD & SE \\
\hline GR A & 20 & 6.72 & 1.81 & 0.41 \\
\hline Gr B & 19 & 8.07 & 0.59 & 0.13 \\
\hline
\end{tabular}

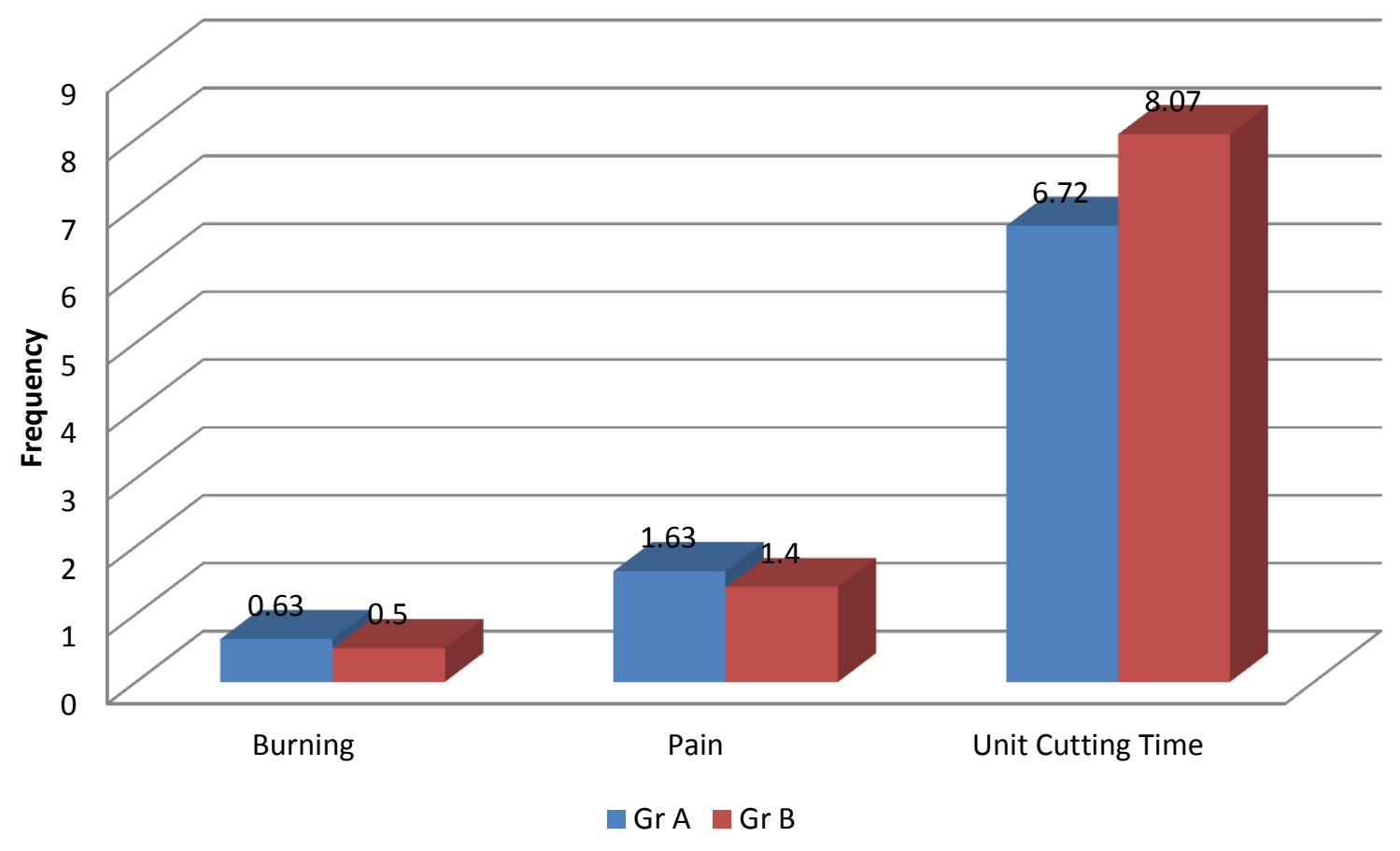




\section{Unit Cutting Time}

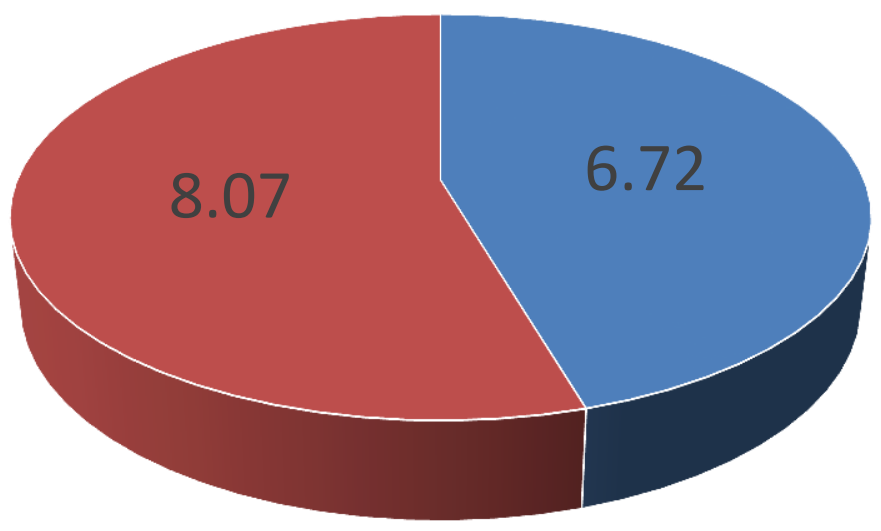

\section{- Gr A - Gr B}

\section{Discharge Difference:-}

\begin{tabular}{|c|c|c|c|c|c|c|}
\hline \multicolumn{5}{|c|}{ Descriptive Statistics } & & \\
\hline \multicolumn{2}{|c|}{ Group } & $\mathrm{N}$ & Mean & Std. Deviation & Man Whitney & P Value \\
\hline Group A & discharge & 20 & .65 & .49 & 163.5 & 0.34 \\
\hline Group B & discharge & 19 & .79 & .42 & & \\
\hline
\end{tabular}

\section{Discharge

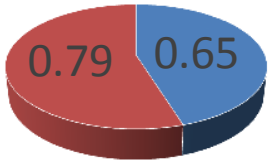 \\ - Gr A - Gr B}

Pain:-

\begin{tabular}{|c|c|c|c|c|}
\hline Pain & N & Mean & SD & SE \\
\hline Gr A & 20 & 1.63 & 0.68 & 0.15 \\
\hline Gr B & 19 & 1.4 & 0.68 & 0.15 \\
\hline
\end{tabular}

\section{Conclusion:-}

Aim of present study is to find out the efficacy and applicability of ArkaksharaSutra in the management of Bhagandara. Based on the above clinical statistical data it may be concluded as follows-

* There was a marked reduction of symptoms of irritation, inflammation, and local reactions in treated group as compared to control group.

* Economically minimised the problems of preparation.

* Wound healing after cut through was faster in treated group(1-2 weeks) as compared to (2-3 weeks) in control group.

* No recurrences of cases were reported during the last 6 months of follow up.

* Easy Availability and Collection 
- Better alternative in place of Apamarga kshara Sutra because it has more acceptability, easily available, reduction in UCT and better wound healing property after cut through.

\section{Scope For Further Research:-}

1. Effect of this preparation should be tried on wound healing and histological changes on the local tissue.

2. Bacteriological study can be carried out to establish the efficacy of this preparation.

3. Kshara Avachurnana in DustaVrana, NadiVrana (nonhealing ulcer) etc.

4. To find out ingredients which can furth er reduce pain and burning sensation

i Shastri Ambikadatt(ed)Susruta Samhita Ayurveda Tatvasandipika hindi Commentary Reprint edition 2014,Varanasi,221001.Chaukhambha Sanskrit Sanstham.sutra sthana 33/4.

ii Supreeth j. lobo,A comparative therapeutic evaluation of tilnala Kshara sutra and snoohi khir sutra and apamarga Kshara sutra in management of bhagandar

iii Shatri ambikadatt,susruta samhita(nidan sthan) ayurveda tatvasandipika hindi commentary reprint edition 2014,Varanasi,chaukhmbha Sanskrit sansthan,4/4,

iv Shatri ambikadatt,susruta samhita(chikitsa sthan) ayurveda tatvasandipika hindi commentary reprint edition 2014,Varanasi,chaukhmbha Sanskrit sansthan,page 101

${ }^{v}$ M.S. Baghel Researches In Ayurveda $2^{\text {nd }}$ Edition .Jamnagar Mridhu Ayurvedic Publication 2005

vi Shastri Ambikadatt(ed)Susruta Samhita Ayurveda Tatvasandipika hindi Commentary Reprint edition 2014,Varanasi,221001.Chaukhambha Sanskrit Sanstham.p 47

${ }^{\text {vii }}$ M.S. Baghel Researches In Ayurveda $2^{\text {nd }}$ Edition .Jamnagar Mridhu Ayurvedic Publication 2005

viii Prof.J. K Ojha,Hand Book of Dravya Guna,Chaukhamba sansthan,Delhi,First edition 2004,Page 26.

${ }^{\text {ix }}$ Sushruta Samhita: with Nibandha Samgraha Commentary by Dalhana and the Nyaya Panjika of Sri Gaya Dasacarya on Nidana Sthana, Chaukhambha Orientalia, Varanasi, 1986. 